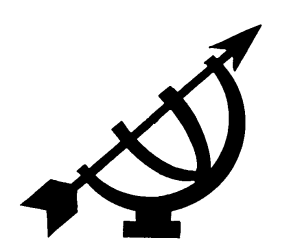

\title{
Contemporary Christian spirituality: a worldly embodiment
}

\author{
C. Kourie \& T.J. Ruthenberg \\ Department of Christian Spirituality, Church History \& Missiology \\ Unisa \\ PRETORIA
}

E-mail: kouricet@unisa.ac.za

trean@mweb.co.za

\begin{abstract}
Contemporary Christian spirituality: a worldly embodiment

Contemporary renascent spirituality secures for itself a motif of materiality and physical embodiment. This embodiment pertains to renascent spirituality both as lived-life experience and particularly as contemporary academic discipline. The influential sources of an embodied spirituality are to be found in spirituality's reflective self-understanding, the rich resources of the Christian tradition, the growing interest in lived Christian experience as such, and the post-Vatican II conciliatory spirit and momentum. Renascent spirituality not only accommodates and endorses embodiment and "worldly" materiality; it also realises a new wholeness and integration for Christian spirituality. While it might seem a commonplace to defend Christian spirituality's embodied, incarnational reality, it is clear that spirituality has not always been so understood, even constituting a pejorative connotation at times as something essentially detached, disembodied and inferentially dualistic. Spirituality in its revived sense holds within itself and its inherited tradition the potential to critique such disembodiment while simultaneously securing the mystery and transcendent dimension of embodied Christian living.
\end{abstract}

\section{Opsomming}

Hedendaagse Christelike spiritualiteit: ' $n$ vergestalting in die wêreld

Die huidige oplewing in spiritualiteit het 'n nis vir materialisme en fisiese vergestalting geskep. Hierdie beliggaming dui op 'n herlewing in spiritualiteit as 'n deurleefde ervaring en ook in die 
besonder, as 'n kontemporêre akademiese dissipline. Die invloedryke oorspronge van 'n beliggaamde spiritualiteit word gevind in spiritualiteit se refleksiewe selfbegrip, in die ryk bronne van die Christelike tradisie, die groeiende belangstelling in deurleefde Christelike ervaring en die versoeningsgees en stukrag van Vatikaan II. Die oplewing in spiritualiteit akkommodeer en bevestig nie net vergestalting en wêreldse materialisme nie, dit bevestig ook 'n heelheid en integrasie vir Christelike spiritualiteit. Terwyl dit algemeen aanvaarbaar voorkom om die Christelike spiritualiteit se vergestalte, geïnkarneerde realiteit te verdedig, is dit duidelik dat Christelike spiritualiteit nie altyd só verstaan is nie. Dit het soms selfs 'n verkleinerende konnotasie gehad as iets wesenlik afsydigs, afgetrokke en gevolglik dualisties. Die "nuwe" spiritualiteit besit op sigself en in sy oorgelewerde tradisie, die potensiaal om so 'n ontliggaaming te kritiseer terwyl dit terselfdertyd die mistieke en voortreflike dimensie van die vergestalte Christelike lewe verseker.

\section{Introduction}

Contemporary Christian spirituality has emerged as a renascent phenomenon in the years following Vatican II (1962-1965). This phenomenon can at least be partly ascribed to the post-conciliar merging of ascetic and mystical theology, and the consequent designation spirituality as the offspring thereof. For many people this has opened the floodgates of mystical and contemplative possibility in Christian experience. The mystical, contemplative category was formerly an inaccessible spiritual domain. That is to say, the vast majority of believers were traditionally confined to asceticism as opposed to the more elevated spiritual heights of perfection and mystical experience. The development of the word spirituality has admittedly been facilitated by other factors as well, including a postmodern context that, in its more optimistic and hopeful expressions, is promotive of such a development. The problem is that spirituality, whether always so designated or not, has at different historical times been conceived in dualistic ways as partitioned off from materiality and the rest of life. The hypothesis being posited in this article is that Christian spirituality, both as lived-life experience and more particularly as emerging academic discipline, evidences a distinctive worldly embodiment and materiality. ${ }^{1}$ This article shows

1 It should be evident that Christian spirituality is spoken of here with qualification (and in a certain idiom) as an emerging contemporary phenomenon and field of study. It is necessary, for the present purpose, to circumscribe spirituality in this way. I do not speak here of a spirituality that serves as an easy synonym for 
that renascent Christian spirituality, either as an everyday lived reality or fledgling academic phenomenon, is characterised by a conspicuous affirmation of embodied and material reality. The following section looks at a few influential definitions of spirituality (in this qualified deliberative understanding), referring briefly to what adds credence, in these definitions, to the hypothesis of spirituality's embodiment.

\section{Towards definitions of spirituality}

A leading Christian theorist and pioneer in academic spirituality says that spirituality, generally described, "is a holistic (italics - CK/TJR) discipline in that its inquiry into human spiritual experience is not limited to explorations of the explicitly religious, i.e. the so-called 'interior life'" (Schneiders, 1989:693). In other words, spirituality so understood, aims at a wider, more world-affirming embodiment. Schneiders (1989:693) adds that as a holistic discipline "the psychological, bodily, historical, social, political, aesthetic, intellectual, and other dimensions of the human subject of spiritual experience are integral to that experience insofar as it is the subject matter of the discipline of spirituality". 2

"devotions" or "prayer life", or a ready substitute for less contemporary vocabulary. To be sure, these latter cases may well be spiritualities, but not in the sense of the renascent phenomenon of spirituality herein described.

Academic spirituality is still in its infancy and has not clearly articulated and delineated its scope of investigation. It has its champions and sceptics. Some have argued that the integral dimensions enumerated above are too many, and the enterprise far too ambitious and incohesive. Notwithstanding, these dimensions indicate spirituality's appreciation of grounded earthiness and embodiment, which is all I am trying to show here. More seriously, a critical reservation about the troublesome complexity of experience is hardly reason for leaving it unattended. Academic Christian spirituality essentially balks at a systematic theology or spiritual theology that imagines itself sufficing for Christian experience within the limited confines of its own particularised parameters. My own view is that any theological discipline operates in terms of various areas integral to its own interests. (For instance, a traditional theological prolegomena is in itself an acknowledgement of a wider context and contingency.) If it is critically pointed out that spiritual experience does, in fact, touch on too many areas, making cohesion virtually impossible, then systematic theology or spiritual theology should at least not presume to suffice for all those areas as well. It already has to contend with its own inter-disciplinary subjects. On the other hand, if these theological subjects disavow any such presumption then it means that the specialised and sophisticated area of experience is receiving no attention or superficial attention at best. 
Schneiders (1986; 1989; 1993), a Catholic New Testament scholar, initially applies her mind thoroughly to the historical trajectory of Christian spirituality, or the more primitive word spiritual, variously nuanced and understood through the Christian ages. For example, spirituality of the twelfth century took on a philosophical meaning that essentially opposed it to materiality and corporeality. In the next century a juridical meaning emerged, while the seventeenth century gave spirituality a sense of synonymity with the interior life only. Schneiders (1989:681) explores these understandings against the backdrop of renascent Christian spirituality, tracing the emergence of the latter (again) inchoately from the early twentieth century and gaining definitive momentum at, and shortly after, Vatican II (19621965). Her writings have become influential in fuelling interest in academic spirituality and fostering greater reflection on the subject per se. ${ }^{3}$ Schneiders gives an all purpose description of spirituality popularly used by other theorists on spirituality as a suitable yardstick for clarification and debate. She says that spirituality today has to do with "self transcendence which gives integrity and meaning to the whole of life and to life in its wholeness by situating and orienting the person within the horizon of ultimacy in some ongoing and transforming way" (Schneiders, 1986:266). The concern to give a wider, integrative and holistic dimension to the understanding of spirituality is evident in the latter quotation and bespeaks a concern for material embodiment of spirituality or "life in its wholeness". A still wider quoted definition of Schneiders (1986:266) says that "spirituality refers to the experience of consciously striving to integrate one's life in terms not of isolation and self-absorption but of selftranscendence toward the ultimate value one perceives". Dangers of disengagement from embodied life and diminution of the breadth of spirituality are in evidence as concerns here. Within the wider context of spirituality in general, Schneiders then offers a definition of Christian spirituality: "We might define Christian spirituality as that particular actualization of the capacity for self-transcendence that is constituted by the substantial gift of the Holy Spirit establishing a

3 Other scholars, researchers and pioneering writers, with Schneiders, have comprised a seeming "team" of contributors in profiling spirituality or making tentative definitions of spirituality along similar lines to Schneiders (Breton, 1988; Collins, 1996; 2000; Cousins, 1985; 1990; 2000; McGrath, 1999; Sheldrake, 1991; 1998; Principe, 2000). Academics from various theological disciplines are now making contributions to spirituality. One gets the impression that an increasing number have, strictly speaking, ventured outside the parameters of their respective disciplines to do so. To me this speaks of a void in the wider faculty. 
life-giving relationship with God in Christ within the believing community. Thus Christian spirituality is trinitarian, christological, and ecclesial experience" (Schneiders, 1986:266). In this definition Schneiders roots Christian spirituality in the embodied, "believing community". Given that Schneiders' all-encompassing definitions for "spirituality in general" have a real component of holism and integration about them, it should be clear that those qualities also pertain, in her mind, to Christian spirituality, being part of that generality. Indeed, one cannot entirely divorce "spirituality in general" from Christian spirituality and interpret Schneiders thereby. For the latter, spirituality as expressive of transcendence and ultimate value is something that everyone has in common. But what germinal, nascent evidence of embodiment emerges in spirituality's re-constituted, re-emergent format?

\section{Primary evidence of embodiment}

Contemporary spirituality began to evidence a distinctive resurgence after Vatican II and was not always the buzzword it is now. That some mainline denominations have adopted spirituality (hopefully not as a vague formulaic coinage) for themselves is itself a phenomenon. ${ }^{4}$ In the re-emergence of spirituality, what inherent or primary evidence is there of an appreciation of embodiment? Might it be claimed that embodiment is somehow intrinsic to the nature of renascent spirituality?

\subsection{A nascent co-inherence}

If a renascent spirituality clearly gained momentum and revised definition after the landmark, conciliatory event of Vatican II, largely collapsing ascetical and mystical theology into spirituality, then a preliminary postulate might be ventured at this point. The postulate is that, in the general tenor of the Vatican Council's wider conciliatory spirit, the rich mystical or contemplative dimension of 
spiritual theology began to permeate the more ascetical, bodily expression of Christian devotion. This phenomenon could be otherwise described as a move away from ascetical-mystical theology as a kind of static, differentiated discipline, to the more fluid and mutually-penetrative spirituality (Sheldrake, 1991:32-33). In other words, this blurring of ascetical and mystical theology as formerly discrete categories would have assumed the manner of a mutual permeation (or pericar ńsis, in Trinitarian terminology), at once endorsing and enlivening the ascetical dimension, while also investing mystical and contemplative life with a significant embodiment. In any event, notwithstanding this postulate, it seems safe to assume that the unilateral barriers that began to crumble at Vatican II would more than vindicate such an explanation. Of course, it might be argued that such spirituality pertained only to catholicism, and has remained exclusively so. However, the widespread interest in aspects of spirituality hitherto inaccessible to many Christians, or the emergent interest in academic spirituality, hardly bears out a contemporary phenomenon exclusive to catholicism. Rather, the synthesis of ascetical and mystical theology, albeit an initially catholic phenomenon, has been a significant impetus and agent for a new co-inherence or pericarńsic of formerly discrete categories or subdivisions, formal or otherwise. Neither is it being necessarily denied that other unifying global forces (in addition to the Conciliatory Council) conceivably played a significant role in spirituality's resurgence.

\subsection{Experience as embodiment}

Also related centrally to the germinal reformation of spirituality is the word experience. It is a word that evokes embodiment of various kinds, relating unilaterally to various dimensions of embodied livedlife. Regarding the groundbreaking, influential work of Schneiders, in particular, one notes her use of the word experience and the way it operates peripherally to engage a wide dimension of grounded, lived experience. Speaking of spirituality she says that "I am in complete agreement that, whatever the term means today, it denotes experience" (italics - CK/TJR; Schneiders, 1986:265). 5

5 Schneiders is concerned that experience cannot simply be subjected to the more creedal, doctrinal disciplines of theology. These disciplines largely act in an imperialistic, subjugating way when they purport to dispense directives to Christian experience. Can spiritual theology, then, be an option for the discipline that deals with spirituality? Schneiders (1989:686) maintains that spiritual theology has time-bound relevance, not least of which is the division between ascetical and mystical theology - a division that has dissolved into spirituality. It 
Sheldrake (1991), in like manner, appreciates the centrality of experience and the way it has been formative in the resurgence of spirituality. "In recent decades, there has been a shift in the general approach to theology towards a greater reflection on human experience as an authentic source of divine revelation." (Sheldrake, 1991:33.) He goes on to say that "the realisation has emerged that specific spiritual traditions are initially embodied (italics - CK/TJR) in people rather than doctrine and grow out of life rather than from abstract ideas" (Sheldrake, 1991:33). It is clear, furthermore, that Sheldrake understands experience as primarily having to do with everyday, embodied situations rather than the supernatural inbreaking of distinctively other-worldly religious interventions or, for that matter, the easy prescription of systematic theology. In this again, Sheldrake is fundamentally in accord with Schneiders. The everyday, embodied secular world becomes the proper starting place for spiritual experience. Tradition and discursive theology are not simplistically applied as the measure of spirituality. If spirituality is substantially experiential it cannot be exclusively prescribed to by a theological discipline that is characteristically different in kind.

Operating creatively in the nascent formulation of academic spirituality Sheldrake (1991:33) refers to a "secular-dialogic" that must be obtained for spirituality. In his elucidation of this dynamic, or giveand-take dialectic, Sheldrake first promotes the legitimacy of the secular, experiential, embodied reality of spirituality. For Sheldrake, as for Schneiders, doctrinal theology may not be given the licence of exercising premature closure for Christian experience. Secular, embodied spirituality as experience has to speak in some way for itself. As a descriptive and analytic discipline, as opposed to prescriptive and evaluative, the task of the spirituality-theologian "will be to try to understand the phenomenon on its own terms, that is, as it was actually experienced by Christians" (Schneiders, 1986:267-268). Sheldrake, once more not unlike Schneiders in sympathies, seems to establish what he calls a dialogic as the normative gauge or theory for spirituality as a discipline. The dialogic, so termed, operates vigilantly and critically on the frontier of contemporary lived-life experience on the one hand and the particular Christian tradition in

is precisely this strong differentiation inherent to spiritual theology that she feels cannot speak to spirituality, contemporarily understood. For Schneiders, spiritual theology also enhances the impression of spirituality's subservience to systematic theology. Systematic theology then takes (or resumes) the role of a prescriptive patron that prematurely forecloses on experience on the grounds of premises foreign to experience itself. I find Schneiders' reasoning convincing. 
question on the other. In terms of internal constitution, this dialogic comprises spiritual theory and practice.

Waaijman (2002:367) understands academic spirituality as a reflection on the phenomenon of spirituality from two major perspectives. These are the "intra-disciplinary" and the "inter-disciplinary" or inside and outside perspectives. The intra-disciplinary perspectives are delineated as treatises on perfection, mystical theologies, ascetic theologies, spiritual theologies and the perspective of experience. Particularly interesting and significant is the order in which these intra perspectives are placed. It is clear from Waaijman's treatment that they are more or less chronological, with experience the most recent to emerge. "Beginning in the 1960 s as a reaction to the dogmatic-historical perspective of deduction, we witness a shift in the direction of experience (induction)" (Waaijman, 2002:385). This chronology clearly squares with that of Schneiders who sees a greater contemporary place being given to experience in renascent or contemporary spirituality. That is, life-on-the-level-of-experience, embodied life, acquires a stronger normative influence than before. The place of experience in Waaijman's major treatment is further borne out by his inclusion, among the more traditional inter-disciplinary perspectives, of psychology and sociology (Waaijman, 2002: 414-422). These perspectives undoubtedly give a greater anthropological, bodily and material character to spirituality. Moreover, the latter perspectives of experience and the social sciences resonate with formerly unrecognised dimensions of physicality in historical asceticism or in the mystical writings of women. Feminist spirituality recognises how integral such mystical writings were to the femininity and physicality of these Christian women of history. 6

Waaijman, in my opinion, offers a tantalising outline and infrastructure for spirituality. His spirituality is also more embracing of mundane lived-life as a whole. Having looked at this nascent work on reemerging spirituality one feels strongly with Schneiders that spirituality has a field of study and operation that is not accounted for by systematic theology or even spiritual theology for that matter. Waaijman's seminal work makes a compelling case for spirituality's (multidisciplinary) academic independence. It is one thing for theologians to be doctrinaire and seemingly generous about the indispensability

6 For that matter, speaking for the masculine gender, St. John of the Cross' (1542-1591) embodied physical struggle played no small part in his spirituality either, as with Ignatius Loyola (1491-1556) or Dietrich Bonhoeffer (1906-1945). 
and givenness of embodied experience to spirituality or theology as if it needs no defending. It is another thing, it seems to me, to put in place those diversified theological disciplines that will undermine the insidious dualisms that still prevail. Waaijman has achieved this in significant ways. Next I will look at the way in which spirituality's understanding of the Pauline juxtaposition of spirit and flesh secures an integral sense of physical embodiment for resurgent spirituality.

\subsection{Spirit and flesh}

I have been deliberately provocative, as opposed to lax, in choosing the subtitle spirit and flesh, as the heading is meant to hint at the easy manner in which these words can be used, quite oblivious of their freighted, technical meaning in the apostle Paul's thought. Clearly, even in Christian history the words spirit, spiritual and flesh have from time to time acquired different meanings, inviting a number of impositions and presuppositions. The hypothesis of this particular subheading is that, by formally and widely grappling with the apostle Paul's understanding of these words, emergent Christian spirituality secures a pervasive sense of physical embodiment for itself.

First, a number of theorists and theologians in spirituality are particularly concerned to deal with the apostle Paul's (1 Cor. 2 ff.) understanding of spirit and flesh or show it to be primarily definitive and obligatory for any work on spirituality. Where these scholars do not in each case specifically elucidate the significance of spirit and flesh in Pauline theology (and for the most part they do), they operate out of a transparent awareness of its paradigmatic and normative place in all thought on resurgent spirituality (Carson, 1994: 381-382; Collins, 1996:77-78; Guiterrez, 1983:64-70; McBrien, 1987:89; Principe, 2000:45; Schneiders, 1986:256; 1989:681; Sheldrake, 1991:34; Stringfellow, 1984:22). Secondly, it is critical to note that each theologian (surely together with the apostle Paul) is intent on showing that spirit and flesh have to do with two different attitudes or dispositions in life. In other words, spirit and flesh are not informed by the distinction between the non-material and the material, the disembodied and the embodied, but by the understanding of two different ways of life. That is, there is nothing exclusively immaterial or disembodied about the spiritual life, or certainly not in the Pauline sense. Thirdly, since each of these writers is well versed in the history of spiritual and spirituality and the various nuances and shades of the words, it can be supposed, given their emphasis, that they wish to speak in a corrective way to past and present 
distortions - especially as they invariably refer to spirituality's periodic historical corruption. Fourthly, each of these writers is involved in a specialised, academic intentionality with spirituality as such and not just in terms of spirituality as a non-descript contemporary neologism. Given their particular field of research and reflection, then, it has to be said that spirituality shows a particular concern for (worldly, in the words of the title) embodiment, vouchsafed by a wide representation of exponents. ${ }^{7}$ In this sense, spirituality in the Pauline sense is a new way of living in and through the physical body as opposed to an alternative disembodied or body-denying position, where the latter is mistakenly identified with spirit or spiritual. These theorists on Christian spirituality are at pains to point this out. It is reasonable to suggest that these writers also speak under influence of globalisation and a few notable postmodern convictions. That is to say, they appreciate the inter-relatedness and dependency of all things, not least of all the connectedness of our human embodiment with other forms of life and with universal physicality in general. Given the mutual contingency of planetary physicality and human embodiment in this persuasion it should be appreciated that spirituality already implies a wider embodiment than that of the human body. In other words, one might plausibly suppose a logical trajectory from spirituality's endorsement of human physicality to an endorsement and appreciation of the sacredness of all materiality, or perhaps even the other way round in some persuasions.

\subsection{Embedded spirit}

Another primary evidence of embodiment in renascent Christian spirituality is spirituality's embedding of spirit in the embodied humanity of each and every person as a kind of permanent constituent of a human being. However this is to be understood, or whether every Christian tradition can agree, the integral identification and inseparability of body and spirit in re-emergent spirituality seems to embed the spiritual dimension most securely in human physicality. In the

$7 \quad$ The word worldly have been used in the title as evocative of a now mostly dated adjective that sought to indicate a sinful, indulgent way of life - one which presumably enjoyed this world and its physicality too much. The word almost surely betrayed Christian suspicion about materiality's bona fides. The use of worldly, of course, deliberately seeks to expose this subliminal suspicion so as to recover previously outlawed dimensions of embodiment. More so, worldly as used in the title is meant to undermine a spurious understanding of spirituality. 
preface to a monumental work on spirituality, which is likewise part of a wider series, Cousins (1985) speaks of "the spirit". He says:

This spiritual core is the deepest center of the person. It is here that the person is open to the transcendent dimension; it is here that the person experiences ultimate reality. The series explores the discovery of this core, the dynamics of its development, and its journey to the ultimate goal. (Cousins, 1985:xiii.)

It is clear that Cousins has an interest in forging "a new discipline in the field of religion, the discipline of spirituality". As with Schneiders, he believes that spirituality (and this pertains in like manner to Christian spirituality as constituent thereof) "needs to be accorded its own place in academic studies ..." (Cousins, 1985:xiii). More to the point, however, Cousins achieves a consolidation of body and spirit that essentially enhances and promotes spirituality's embodied character. In other words, the spirit is to all intents and purposes wedded to human physicality. Of course, my purpose is not to evaluate this position after the approach of various Christian traditions, but rather to underscore renascent spirituality's primary propensity for securing physical embodiment in general, and certainly in Cousins' (1985) telling preface to this impressive volume in particular (McGinn et al., 1985).

Related to the sense of embeddedness herein described is Schneiders' assertion that spirituality's point of departure, methodologically speaking, needs to be anthropological. This assertion is entirely consistent with her view that spirituality, at least in part, relates to "a fundamental dimension of the human being ..." (Schneiders, 1989:678) Homo sapiens are spiritual beings, homo spiritualis; beings capable of transcendence. $\mathbf{8}$ In other words, for Schneiders there is a kind of domiciled inherence or embeddedness about the spirit's housing in human physicality. She supports Breton (1988:101), who argues that the spiritual life "could be described as a way of engaging anthropological (italics - CK/TJR) questions and preoccupations in "supernatural existential" or openness to the infinite, in contrast to Aristotle's (384-322 BC) definition of the person as a rational animal (McCool, 1975:185190). One is aware that Schneiders' view is not amenable to all Christians. Some Protestants would have difficulties. "In this setting, Arminians would undoubtedly champion the salutary effects of prevenient grace and Calvinists those of common grace. But the capacity for transcending oneself, of receiving a call to some higher value or meaning, is not evidenced by theists alone." (Collins, 1996:86.) 
order to arrive at an ever richer and more authentically human life". Following the deliberations of Breton (1988:103) she says that "[f]or the anthropological approach the structure and dynamics of the human person as such are the locus of the emergence of the spiritual life. Spirituality is an activity of human life as such" (Schneiders, 1989:678). Further, not only is spirituality a fundamental dimension of the human being but it is also the substance of the lived experience which actualises that dimension (Schneiders, 1989: 678). ${ }^{9}$ According to the tenor of these qualifications, Schneiders advocates an anthropological position for spirituality or definition "from below" in contrast to a dogmatic position, which she sees as operating prescriptively "from above" in a manner that is contrary to the nature and operational field of spirituality as such. More pertinently, spirituality in this definitive sense aspires to, and acquires, an appreciable measure of determinate physicality.

\section{Spirituality: generic and diverse embodiment}

\subsection{Explanatory preamble}

This section proposes to show that renascent (or contemporary) spirituality, whether understood as a distinctive generic phenomenon or in terms of differentiated diverse manifestations, exhibits an aspiration for, and consciousness of, material embodiment. It is now a standard practice among theologians to caution that there is no such thing as a generic spirituality. On the basis of unilateral evidence, this caution is vital and cannot be gainsaid. Spirituality is determined or coloured by a host of contextual factors. I have tried to show that out of Christian spirituality's historical development, inter-disciplinary relationships, and theological nuances has emerged a distinctive, collaborative reflection on spirituality beginning more definitively after Vatican II. There has been a consensual and academic endeavour to understand spirituality's re-emergent seminal contribution for our theological era. Moving within the school of these pioneering thinkers on spirituality, one becomes aware of a

9 Schneiders invariably emerges as an unofficial spokesperson and inspiration for spirituality in its contemporarily seminal form and is frequently quoted by other reflective theologians in this field. Thus Collins (1996:85) also uses Schneiders' basic referents to describe contemporary spirituality, namely that spirituality is a fundamental dimension of the human being, the lived experience which realises that dimension, and also the academic discipline which studies that experience. Collins (1996:85) makes the point that the last two referents have been well explored, but that the first one has not received extensive treatment. 
significant, purposeful (perhaps corrective) impetus to claim physical embodiment for spirituality, not to mention an obvious move towards dealing with spirituality on its own terms. In this qualified sense, at least, there might be some value in speaking of a generic spirituality, especially if serious theological and historical attention is to be given to the word; that is, in contrast to spirituality's disintegration into faddish meaninglessness.

There are, however, specialised spiritualities that seem to be persuasively linked to the renascent, more or less generic spirituality that has herein been described. These are feminist spirituality, liberation spirituality and creation spirituality. Their ecumenicity gives credence to their membership in the spirituality family in general, in contrast to the later customisation of spirituality into various denominational groupings. These three ecumenical spiritualities seem more prototypically expressive of resurgent spirituality than regulatory denominational annexations thereof. Together with these three expressions is the often unnoticed influence of what might be referred to rather nebulously as postmodern spirituality. The first three expressions enumerated (leaving aside the less intentional and formal postmodern variety) operate with the denotation, spirituality, in each case. Though not unrelated to systematic theology, they are not presented in that format - or certainly not exclusively so. They seem to be the fruit of lived-life experience and, consequently, operate in the field of spirituality as such - a forum arguably more amenable to reflective (auto)biographies and experiences. Their membership of the distinctive family of spirituality is further identified by their endorsement of various forms of material embodiment. Attention, albeit briefly, is drawn to these conspicuous endorsements below.

\subsubsection{Feminist spirituality}

Feminist spirituality originated in the 1980s, "giving voice to and celebrating bodiliness, especially the experiences associated with reproduction and childbirth, experiences which have frequently been viewed as inferior" (Waaijman, 2002:218-219). Because of the social pressures and biases traditionally visited on women, it has probably taken the assertiveness of a spirituality more appropriately referred to as feminist - rather than the tamer designation, feminine, as designated by Ring (1983:148) - to make women's presence felt. The brave contribution of feminist spirituality has been a timely affirmation and endorsement of femininity and the female experience of embodiment as integral to Christian life and reflection. Women's thought in this regard constitutes a spirituality because it demonstrably emerges from women listening to their own experiences, 
bodies, thoughts and instincts. Out of this largely experiential attentiveness has come the discovery that such a feminine experience speaks to a considerable void and bias in (largely male-dominated) systematic-theological discourse. Moreover, feminist spirituality and its passionate reclamation of female embodiment realises an appraisal and affirmation of the place of sexuality - demonstrably for women, but contingently not without a significant impact on the understanding of sexuality in general. Summarily speaking one might say that feminist spirituality evidences a healthy blend of rigorous thinking and personal identification. It furthermore underscores, and takes seriously, the meaning of the primordial Adam. The latter, of course, refers to humankind inclusively rather than to the skewed exclusivism of Man and Mankind.

Feminist spirituality - traditionally conscious of the sexual inclusivity and embodied entirety of the imago dei - has done much to elevate the place of the human body in theologically understood revelation. Body theology is a phenomenon in feminist spirituality, and significant advances are evident in the field. Prokes (1996), Isherwood and Stuart (1998) and McFague (1987) offer stimulating insights. Body theology shows how the human body might be a vehicle of (sacramental) revelation to others. That revelation may be selfrevelation or revelation of God. Prokes (1996:90) explains how the human body "is revelatory of the whole person, a Real Symbol. Each human person is a visible, meaningful word spoken bodily into the world". 10 The insights of body theology, at least in their reflective aspiration and intent, help show that the human person is a composite whole. Illustrative of this are Prokes' (1996:90) words that when the "outward expression and inner intent are in accord, the more perfectly is the body-person realized as Real Symbol".

It is informative to note how the concept of the body becomes more expansive in the spirituality of Sally McFague (1987). Working in a frontier area between feminine experiential spirituality and theology she encourages the imagining of the world as God's body.

It is not to say that the world is God's body or that God is present to us in the world. Those things we do not know; all that resurrection faith can do is imagine the most significant ways to speak of God's presence in one's own time. And the metaphor of the world as God's body presents itself as a promising candidate. (McFague, 1987:61.) 
The materiality of spirituality is in evidence again in the work of King (1997). Working with the thinking of Teilhard de Chardin (18811955) she says: "The world as God's body is a rich metaphor for contemporary ecological and sacramental theology ..." (King, 1997:69). The use of images of embodiment (and kindred procreation) is further recommended with respect to the Trinity. McFague (1987:135-136) says that "[t]he model of God the creator as mother suggests an ontological (or cosmological) sacramentalism: the world is born from the being of God and hence will be like God". The image of the Saviour as lover is another innovation of McFague's (1987:135-136), evoking the further imagery of physicality, relationality and sexuality. This is no accident as the writer also speaks of God as lover in the sense of eros (McFague, 1987: 132). The relational, physical imagery of motherhood, sexuality and even eroticism seems to be consistent with McFague's (1987:145146) conviction that salvation is not something that happens to us so much as it is something we participate in.

It should be noted that the contribution of hitherto marginalised women thinkers and devotees in Christian history has contributed substantially to the emergence of feminine and feminist spirituality. The stories and spiritualities of these (for the most part) ignored women are now readily accessible and popular. Such exemplary figures include, inter alia Julian of Norwich (1342-1420), Catherine of Siena (1347-1380), Teresa of Avila (1515-1582) and, more contemporarily, Simone Wei (1909-1943). It is particularly significant how a number of these women lived through times of serious physical affliction and infirmity and utilised their own sense of womanhood, physical struggle and embodiment in their spiritual experiences. This has not gone unnoticed in embodied feminist spirituality.

Finally, it is particularly to the credit of feminist spirituality that it has such a universal perspective and gender friendly applicability and pertinence. In this sense it is, in my opinion, admirably holistic and physically embracive.

\subsubsection{Liberation spirituality}

Liberation spirituality (in my opinion, still short on literature and somewhat amorphous) nevertheless finds its place in Wakefield's (1983) dictionary on Christian spirituality (Scharper, 1983:247-248). In Waaijman's (2002:217-232) commendable and exhaustive opus on spirituality, liberation spirituality is officially designated as a countermovement spirituality, its exponents "inwardly touched by an allderegulating Presence to which they totally entrust themselves". 
Further legitimating liberation spirituality is the contribution of Guiterrez $(1973 ; 1983)$ himself, for many a name synonymous with liberation theology. In a work more identifiable as spirituality, or lived experience in relation to the liberation struggle, Guiterrez manifestly tackles the subject of spirituality as such. Much like the circle of thinkers in what I venturesomely referred to earlier as generic spirituality, Guiterrez also grapples with the apostle Paul's understanding of spirituality, flesh, spirit and body. He exhibits, in my view, a distinct kinship with renascent spirituality in its deliberative, etymological and historically informed sense, and sees it worthy of address. ${ }^{11}$ Speaking of the term spiritual he says: "It is indeed a central and rich concept, but also, it must be acknowledged, one open to equivocations that unfortunately have darkened many periods of the history of spirituality." (Guiterrez, 1983:54.) This liberation theologian has a high view of the word body in the apostle Paul's writings as referring to a physicality that is also redeemed through Christ's work. Thus there is a distinction between the "body of flesh" and the "spiritual body" (Guiterrez, 1983:65-67). This spiritual body, however, is not something mysterious or impalpable. It is a present reality but of a different order and disposition to the "body of flesh". It is in this familiar way of going back to Pauline theology to secure physical embodiment that Guiterrez shows himself to be in line with the characteristic treatment of spiritual and spirituality in this article. The full and intentional reclamation of the embodied person forms the basis and sustenance for Guiterez's liberation spirituality. Most encouraging and not always evident among liberation theologians is the insight in Guiterrez that liberation needs to be approached in a contemplative and prayerful manner.

... Christian spirituality consists in embracing the liberated body and thus, being able to pray 'Abba, Father!' and to enter into a comradely communion with others. (Guiterrez, 1983:70.)

11 This is the distinctive stature and gravity I accord to spirituality. I recognise, though, that it has become an all-purpose unconscious word today. One therefore has to spend no little time elaborating and substantiating everything when spirituality is the subject. I have taken some pains in this article to champion a serious regard and respect for spirituality. Christian spirituality comes with the recommendation of its own historicity, as a legacy that must be reclaimed and strenuously reflected on in the light of its own traditio and background. Any theological subject, if it is worth anything at all, needs to deal with its nascent and developmental history in order to make contemporary sense of it. Following thereon is the responsibility of custodianship and on-going critical hermeneutic. Spirituality, however, frequently evokes academic suspicion or a display of almost culpable theological ignorance. 
This approach by no means undermines the hard realities and challenges of "people on the ground". Expressed more accurately, it is being discovered that a contemplative and prayerful perspective is the only one that can see political suffering in all its reality, neediness and possibility. In this regard, Thomas Merton (1915-1968), the catholic contemplative and monk, was an exemplar and enormous influence for the kind of politically involved spirituality that heralded a new dawn for modernistic society, trapped as it often was in a pejorative spirituality together with its causative dualism. What is of further importance for liberation spirituality, of course, is the way it embraces society and the political spectrum as part of that wider body crying out for Christ's redemption. That is, social embodiment as structure, power and principality is also taken seriously as operating within the scope of spirituality.

\subsubsection{Creation spirituality}

Fox $(1983 ; 1991 ; 1999)$ is the contemporary originator and exponent of creation spirituality. He endeavours to recover a wider dimension and embodiment for spirituality as extended to all creation. The nexus and assertion of his creation-centred spirituality is that spirituality must begin with the creation and the cosmos. Theology has been too narrow in perspective. There needs to be a letting go of forms of religion based exclusively on the narrower fall - redemption theologies, spiritualities and systems. In this view, these exclusively historical spiritualities betray dualistic presuppositions, providing a blinkered picture. Spirituality must be "transformed into that tradition which is more ancient, more celebrative, more justice oriented, and more like the tradition Jesus himself lived and preached" (Fox, 1983:305). Fox highlights creation spirituality's precedent for taking its cosmic approach. Irenaeus (c. 130-200), St. Benedict (480-547), Hildegard of Bingen (1098-1179), St. Francis of Assisi (1181-1226), Meister Eckhart (1260-1328), Julian of Norwich (c. 1342-1420), George Fox (1624-1691) and Teilhard de Chardin to name a few, were all, as Fox (1983:100) points out, part of this tradition.

One may have serious reservations about creation spirituality thus expounded, but still appreciate how it lends a sense of embodiment (though perhaps of another dimension) to contemporary spirituality. In this regard, it is part of the embodiment motif in spirituality that this article has initially hypothesised. Creation-centred spirituality corrects surreptitious notions of materiality as being somehow evil or of negligible value. Whether this spirituality can stand on its own as self-sufficient and balanced must be controversial. Certainly, in my 
view, it has insufficient sense of transcendence and lacks a credible eschatology. In its own endeavour to correct imbalances, moreover, it might well have succumbed to a dualism of its own. Nevertheless, together with creation-conscious figures of Christian history, some expressions of postmodernism and with contemporary interest in Celtic spirituality, creation spirituality speaks to deep concerns and crises with respect to the planet earth. It shares a commonality in renascent spirituality of seeking to sacralise all things or make everything the subjectmatter of God's redemption and affirmation. In the words of the Priestly writer: "... and God saw all that he had made, and it was very good" (Gen. 1:31).

\section{Conclusion}

Contemporary Christian spirituality, understood in its renascent sense, evidences physical embodiment as an inherent, almost prototypical part of its self-understanding. This becomes particularly clear in the documented reflections and deliberations of theorists in academic Christian spirituality referred to in this article. The deliberative and purposive propensities of spirituality, both in its more or less generic form but also in its diversification into, for example, feminist, liberation and creation spiritualities, collectively evidence a realisation of embodiment and physicality. The causative explanation for this embodiment is complex and less easy to determine. The opening of the watertight compartments of ascetic and mystical theology that followed Vatican II obviously made for a new holism. That new development, at least from a catholic point of view, facilitated the mutual permeation of ascetic physicality and the mystical, contemplative tradition. It seems, hereby, that the extensive and rich heritage of catholic spirituality therein also became more accessible unilaterally and ecumenically to a diminished and incomplete asceticism or theological spectrum as a whole. Suffice to say, in beginning with the foundational securing of physical embodiment, spirituality secures a worldly embodiment that evidences an even wider contingency.

\section{List of references}

BLOESCH, D.G. 1988. The crisis of piety. Colorado Springs: Helmers \& Howard.

BRETON, J.C. 1988. Retrouver les assises anthropologiques de la vie spirituelle. Studies in religion/Sciences religieuses, 17:97-105.

CARSON, D.A. 1994. When is spirituality spiritual? Reflections on some problems of definition. Journal of the Evangelical Theological Society, 37(3):381-394. 
COLLINS, K.J. 1996. What is spirituality? Historical and methodological considerations. Wesleyan theological journal, 31:76-94.

COUSINS, E.H. 1985. Preface to the series, (In McGinn, B., Meyenedorff, J. \& Leclercq J., eds. Christian spirituality: origins to the 12th century. New York: Crossroad. p. xi-xiv.)

COUSINS, E.H. 1990. What is Christian spirituality? (In Hanson, B.C., ed. Modern Christian spirituality: methodological and historical essays. Atlanta: Scholars Press. p. 39-44.)

COUSINS, E.H. 2000. A spirituality for the new axial period. (In Collins, K.J., ed. Exploring Christian spirituality: an ecumenical reader. Michigan: Baker Books. p. 83-89.)

FOX, M. 1983. Original blessing. Santa Fe: Bear.

FOX, M. 1991. Creation spirituality: liberating gifts for the peoples of the earth. San Francisco: Harper.

FOX, M. 1999. A spirituality named compassion: uniting mystical awareness with social justice. Vermont: Inner Traditions.

GUITERREZ, G. 1973. A theology of liberation. New York: Orbis.

GUITERREZ, G. 1983. We drink from our own wells: the spiritual journey of a people. London: SCM.

HANSON, B. 2000. Spirituality as spiritual theology. (In Collins, K.J., ed. Exploring Christian spirituality: an ecumenical reader. Grand Rapids: Baker Books. p. 242-248.)

ISHERWOOD, L. \& STUART, E. 1998. Introducing body theology. Sheffield: Sheffield Academic Press.

KING, U. 1997. Christ in all things: exploring spirituality with Teilhard de Chardin. London: SCM.

McBRIEN, R.P. 1987. Ministry: a theological, pastoral handbook. San Francisco: Harper \& Row.

McCOOL, G.A., ed. 1975. A Rahner reader. London: Darton, Longman \& Todd.

McFAGUE, S. 1987. Models of God: theology for an ecological, nuclear age. Philadelphia: Fortress.

McGINN, B., MEYENDORFF, J. \& LECLERCQ, J., eds. 1985. Christian spirituality: origins to the 12th century. New York: Crossroad.

McGRATH, A.E. 1999. Christian spirituality: an introduction. Oxford: Blackwell.

PRINCIPE, W. 2000. Toward defining spirituality. (In Collins, K.J., ed. Exploring Christian spirituality: an ecumenical perspective. Michigan: Baker Books. p. 43-54.)

PROKES, M.T. 1996. Toward a theology of the body. Edinburgh: Clark.

RAHNER, K. 1966. Theological investigations. London: Darton, Longman \& Todd.

RING, N.C. 1983. Feminine spirituality. (In Wakefield, G.S., ed. A dictionary of Christian spirituality. London: SCM. p. 148-150.)

SCHARPER, P. 1983. Liberation spirituality. (In Wakefield, G.S., ed. A dictionary of Christian spirituality. London: SCM. p. 247-248.)

SCHNEIDERS, S.M. 1986. Theology and spirituality: strangers, rivals, or partners? Horizons, 13(2):253-274.

SCHNEIDERS, S.M. 1989. Spirituality in the academy. Theological studies, 50:676-697.

SCHNEIDERS, S.M. 1993. Spirituality as an academic discipline: reflections from experience. Christian spirituality bulletin, 1(2):10-15.

SHELDRAKE, P. 1991. Spirituality and history. London: SCM. 
SHELDRAKE, P. 1998. Spiritualtiy and theology: Christian living and the doctrine of God. London: Darton, Longman \& Todd.

STRINGFELLOW, W. 1984. The politics of spirituality. Philadelphia: Westminster.

WAAIJMAN, K. 2002. Spirituality: forms, foundations, methods. Leuven: Peeters.

WAKEFIELD, G.S., ed. 1983. A dictionary of Christian spirituality. London: SCM.

\section{Key concepts:}

embodiment

lived-life

spirituality

\section{Kernbegrippe:}

deurleefde ervaring

spiritualiteit

vergestalting 